DOI:10.1515/curie-2015-0021

\begin{tabular}{lcl}
\hline \multicolumn{1}{c}{ A N N A L E S } \\
UNiversitatis & MARIAE CURIE-SKŁODOWSKA \\
LUBLIN - POLONIA & \\
VOL. XXII, 1 & SECTIOK & 2015 \\
\hline
\end{tabular}

Faculty of Political Science, Maria Curie-Skłodowska University in Lublin, Poland

\author{
RADOSŁAW HARABIN
}

Democracy, its collapse and the Jewish question. Comparing
Hannah Arendt's and Zygmunt Bauman's philosophies

\begin{abstract}
The aim of the article is to present Hannah Arendt's and Zygmunt Bauman's theories of democracy and the Jewish question. The paper consists of three sections. In the first one, there are explained the main concepts of their conceptions of democracy. The second one investigates what the collapse of democracy means for both authors. The third one compares Arendt's and Bauman's opinions on the Jewish question. The conclusions explain the main differences and similarities between the researched theories.
\end{abstract}

Key words: democracy, Jewish question, public sphere, Hannah Arendt, Zygmunt Bauman

\title{
PREFACE
}

"It is the same world - and not some landscape on the moon - where the elements which eventually crystallized, and have never ceased to crystallize, into totalitarianism are to be found" [Arendt 1994 (II): 281]. World in Arendt's terms occurred to be the modern world with its problems and potentiality to crystallize into totalitarianism. Society - mass man - its mentality and lack of political bounds were what she stigmatized [Arendt 1961 (I): 199]. Arch evil of our time - as she wrote - had also different roots: they were called: Anti-Semitism, Racism, Imperialism [Arendt 1994 (I): 150]. Her sense of modernity consisted of complex theories. It is difficult to explain her whole standpoint in a short article but certainly it is possible to present chosen concepts. Thus, the first aim of the article was to refer her explanations on 
democracy, its collapse and the Jewish question. In other words, firstly, from the general concept of modernity I selected and investigated problems connected with democracy. Secondly, I focused on antisemitism and narrowed it down to the Jewish question. I treated the combination of those subjects as an interesting issue also to the contemporary reader. It could be worth to rethink weakness of democracy and a problem of minorities which, according to Arendt, are still capable of crystalizing into totalitarianism.

The second goal of the paper was to compare Hannah Arendt's and Zygmunt Bauman's theories. As a generation after the Holocaust we are obligated not to forget about it. It is important not to allow it to happen again. Even if we are not able to understand the Shoah or refer to its reality, we have the duty which cannot be abandoned - remembrance. Introducing to an English language reader the Polish thinker in comparison with the world famous writer is the answer to that requirement. Especially that his world-renowned book Modernity and the Holocaust seems to be more then accurate to that problem. Its content was fundamental to the comparison presented in the article.

The paper consists of three sections preceded by the preface and finalized by conclusions. Research method was based on concepts investigations. Inference term's meaning consists in an analysis of its contextual surrounding. Outcomes were placed in deductive scheme of work. Each paragraph contains helpful explanations for understanding the upcoming one. I began with explanations of democracy in both authors' sense. Later - in the second paragraph - I explained their understandings of the collapse of democracy. Finally - in the third section - I introduced their opinions on the Jewish question. In other words, to explain the meaning of the collapse of democracy I needed to refer the concept of democracy in advance. Against the backdrop of the knowledge on the meaning of the collapse, I was able to place the problem of the Jewish question.

I am proving a hypothesis that Bauman and Arendt are intercessors of participation democracy, but reasons why they treat engagement in public sphere as important are different. Also the Jewish question has an extraordinary sense for both authors. Presented work shows two varieties of that problem. The first one is looking for the reason of the Jews' alliance. The second traces the answer to the question: "Why Jews?". Presentation defends a standpoint which explains those two as a matter of social relations.

\section{CONCEPTS OF DEMOCRACY}

Some researchers explain Arendt's philosophy of democracy as equal to events which could be called participation democracy. According to M. P. d'Entreves, "[Arendt] saw representation as a substitute for the direct involvement of the citizens, and as a means whereby the distinction between rulers and ruled could reassert itself. When representation becomes the substitute for direct democracy, the citizens can 
exercise their powers of political agency only at election day... [for her] democracy [is] based on the principles of freedom, plurality, equality and solidarity" [d'Entreves 2001: 2, 162].

Understanding Arendt's theory as an example of participation democracy ${ }^{1}$ requires at least explaining her main concepts which refer to a public sphere. Her view on organization as relations between people is rooted in her anthropology. Thus, participation democracy written in her terms receives a specific meaning. Her theory of public sphere, concepts of freedom, plurality, and equality are crucial.

For the German thinker, freedom and equality are bound together. Based on her writings both terms receive two complementary meanings: the first one refers to the so-called life necessities, the second one is political. Actually, equality comes from freedom which is understood as independence of the necessities of life and utilitarian aims. In such an understanding, people who cannot support their existence (household, health, food, etc.) and whose patterns of behaviour are motivated by utilitarian aim or external pressure, are not free. Equality reflects freedom. Individualities are not forced by anything to the same extent. Some of them are more skilful, clever then others, but all are starting from the same position. What matters, they will show their own character [Arendt 1998: 11, 214]. Freedom being understood as independence of necessities, equality which means the same starting position enable political freedom and political equality. ${ }^{2}$ Freedom - in that second sense - refers to the actual participation in a decision-making process of a community. Its actuality is visible in Arendt's explanations of action. Action means freedom [Arendt 1961 (II): 151-152]. What needs to be stressed, action is taking place only when it proceeds. In her terms, freedom is also being described as public happiness and that kind of happiness means the participation in community decisions [Arendt and Reif 1972: 203]. Freedom is political because it exists in between people. For Arendt, participation does not mean for example: obeying the law or making it. ${ }^{3}$ In between is bound with human ability to behave spontaneously. The closest metaphor which she uses to describe it is the parallel of the promise [Arendt 2007 (II)]. Realization of the promise depends only on a good will of the person who gives it. Nothing but the person guarantees

1 Elżbieta Matynia and Danna Villa interpreted Arendt's theory in terms of performative democracy, which still needs to be understood as a participatory variant of democracy. E. Matynia, Performative Democracy, Routledge 2009; D. Villa, Arendt and Heidegger, Princeton University Press 1996, pp. 52-59.

2 H. Arendt, On Revolution, Penguin Books 1990, p. 30; and also H. Arendt, Between Past and Future, The Viking Press, New York 1961, p. 148; I found the same observation in Jerome Kohn's article. J. Kohn, Freedom: the priority of the political, [in:] The Cambridge Companion to Hannah Arendt, (ed.) D. Villa, Cambridge University Press, Cambridge 2000, pp. 114-120.

3 H. Arendt, The Human Condition..., p. 63; H. Arendt, Europe and the Atom Bomb, [in.] Essays in Understanding 1930-1953. Formation, Exile, and Totalitarianism, Schocken Books, New York 1994, p. 420; Paul Ricoeur also noted that freedom for Arendt has pre-legislative character. It rises spontaneously out of free and equal debate. P. Ricoeur, Power and Violence, [in:] Hannah Arendt. Critical Assessments of Leading Political Philosophers, Routledge, London, New York 2006, v. 3, p. 396. 
its realization. ${ }^{4}$ Freedom means the action: making promises and proceeding them with other people. Equality comes from the freedom and it is the acceptance of the others. People who cooperate together, who rely on each other guarantee each other their status. The action breeds the equality. People do not choose arbitrarily whom they like or dislike. On a virtue of action people become equal. The realization of the promises brings the acceptance and the confirmation of the status [Arendt 1990: 30].

Arendt's theory of the public sphere is not understood as an independent institution or the one that exists its own life. As she wrote: "not Athens, but the Athenians, were the polis" [Arendt 1998: 195]. The German thinker is describing that as plurality. In The Human Condition she explains what is forming each human being condition, that are: "conditions under which life on earth has been given to man; conditions which were created by human" and "impact of the world's reality" [Arendt 1998: 7-9]. "Conditions under which life on earth has been given to man contains: wornness, birth and depth, plurality, natality and mortality". Each of those conditions allows prosecuting one of human activities: labor, work and activity. In our case, the most important action is being active which is connected with plurality. Activity requires speech to be understandable. Communication is crucial for presenting intentions and not to be misunderstood [Arendt 1998: 177].

Both terms have their own specific meanings, different from what they could suggest in ordinary life. Human plurality, according to the explanations of the author of Origins of Totalitarianism, is a "paradoxical plurality of unique beings" [Arendt 1998: 176]. Otherness does not mean alternative which is based on one's characteristic. It describes one's own character, personality and experience of a particular person. Plurality refers to humans who are unrepeatable. Plurality is connected with the ability to spontaneous activeness. Every existing human because of his uniqueness is able to start extraordinary events.

Public sphere is built with interactions and relations among its members. To explain it in Arendt's terms: "Action and speech go on between men (...), out of which arise (...) specific, objective, worldly interests (...), something which inter-est, which lies between people and therefore can relate and bind them together" [Arendt 1998: 182]. The purpose of being together does not lie in any utilitarian aim. People are staying together not because they are pro or contra something. They are able to create, and what they create binds them together.

From that perspective, democracy needs to be considered as a special type of public interactions but not the political system. That is the outcome of activity. It could be found in the social movements where many involved people are acting together in the name of a common goal. The participatory aspect of cooperation,

4 H. Arendt, The Human Condition..., p. 195; Freedom in Arendt's sense also connects with lie. Since human being is a unique existence able to spontaneous actions, it is also able to lie. H. Arendt, Lying in Politics: Reflections on The Pentagon Papers, "New York Review of Books", 17/8, 18 November 1971. 
the need to take part in a political decision-making process - political freedom - is Arendt's great demand and the fundament of her theory.

In Arendt's thought there is a problem of how to classify democracy, because it could be treated as a frame of public behaviours. As an artifact it should belong to the world of things (wordiness) which, in Arendt's terms, may not be mixed up with plurality. Interactions are obviously previous then their effects. If the public sphere is treated as a being in between of plurality, and excludes effects of activeness as made by man, it will stay undisturbed. Its development would be limited to the history as a collective memory. ${ }^{5}$ If the effects of activity are included in that sphere, the border to them would be freedom and equality, they can break those two.

It is hard to make a clear standpoint in that case. Reflection of that issue is present in the literature on Arendt's thought. For example, A. Heller is trying to prove that freedom is significant to the described sphere of public life [Heller 1987]. A Polish researcher J. P. Hudzik is treating a public field as an effect of social agreement [Hudzik 2002: 86-87]. For the purpose of that work, I am going to treat democracy in Arendt's writings as describing participation democracy and developing it by adding the outcomes of activity.

There is no clear explanation in Bauman's Modernity and the Holocaust about the concept of democracy. The author may use that term but still his explanations are not sufficient to understand his thought right away. In one of the chapters he proposes: "If we ask now what the original sin was which allowed this [Holocaust ${ }^{6}$ ] to happen, the collapse (or non-emergency) of democracy seems to be the most convincing answer" [Bauman 2000: 111]. Furthermore, "after communal mechanisms of social regulation (...) disappeared (...), the void tends to be filled by new (...) supra-communal forces (...). [Those] dislocations may differ in form and intensity, but they are united by the general effect of the pronounced supremacy of political over economical and social power" [Bauman 2000: 112].

Citations which were brought above contain two main thoughts. Bauman conceives the process of democracy as collapsing or at last partially responsible for the Shoah. Secondly, he is describing democracy in terms of a communal activity in social regulations fields.

In investigating what Bauman means when he describes communal involvement [R.H.], and also how he differs political and social behaviors it is easy to recognize

5 For Arendt, the ancients developed the concept of history as a communal memory. People were attending public sphere in hope that theirs acts would be remembered by future generations. That was the only way to become immortal. H. Arendt, Human Condition..., p. 18, and H. Arendt, Between Past and Future..., pp. 43-45.

6 I am conscious that the term Holocaust, could have had different connotations. Deriving it from its religious sense as a burnt offering, I am going to use it to describe a systematic murder committed on the Jewish nation. It has a close connection with two other words: Churban and Shoah. The first one means destroying existing things and beginning for new events. Because of unexplainable sense of the new beginning I prefer using the word Shoah. Its connotation is bound with the uniqueness of the twentieth-century events and also loneliness of the Jews in their experience. 
that the sphere of social life means interactions between humans under nobody's control. Bauman is making sharp distinctions between social and societal spheres. His thought: "context of coexistence (...), being with others, that is, a social context (...); supra-individual agencies of training and enforcement, that is, of a societal context" [Bauman 2000: 179]. Training and enforcement describe influence on somebody's decisions. Desirable appearance of relationships in democracy conditions requires behaviours without an extraneous impact. Opinions can be formed on the basis of communications and reasonable calculations but not on having been manufactured. For the Polish writer, thinking (reasonable calculation) signifies having critical view on a heterogeneous world [Bauman 2000: 178].

If it is necessary to investigate his theory of critical thinking deeper, it should be connected with the analyses of Milgram's experiment. Bauman is using that example to show the impact of authorities on somebody's decision. He is explaining: "what Milgram must have meant by 'real life' was life inside a democratic society (...), under conditions of pluralism". We could ask what is building that pluralism, where are its roots? Explanation could be found in the same text: "unequivocal source of authority (...) [following] own judgment" [Bauman 2000: 165].

Bauman does not distinguish acts of thinking and judging, as Arendt does. It looks like Bauman could mean similar processes of mind activity without precise descriptions. His critical view has similar features to Arendt's thinking as a wind of reason. Her concept of thinking could be explained by four points: speculative character; gives no outcomes; dialogical character and lastly, it does not necessarily have references to the real world [Arendt 1978 (II): 178, 99, 46]. The most important for the tracked argumentation is its speculative character - looking for presuppositions and their foundations. Thinking eliminates all established senses. Judging is bound with common sense which could be understood as a mind operation founded on feelings instead of concepts. Concepts make sense, and the sense is always connected with an individual experience. There is a presupposition that as members of the human species one feels similar enough to choose how the other could behave. ${ }^{7}$ Its outcome has also aspirations to be a general principle, because it is based on convenience of making the right decision. By that, the active person is able to chose the "right way" when there is nothing what is indicating the choice [Arendt 1961 (I): 223-225].

Similarities between Bauman's and Arendt's explanations lie in comparing Arendt's concept of thinking with his idea of critical reasoning and her judging with his plurality of authorities (everybody is entitled to one's own opinion).

Democracy for Bauman is a description of power - as it was shown in the first citation. It is the outcome of human interaction based on critical calculations. Social behaviours require conditions of pluralism - variety of opinions and diversity of

7 Explanation is drawn from the interpretation of sensus communis proposed by J. Szczepański, Polityczna władza sądzenia, WUJ, Kraków 2009, pp. 79-80. 
being (heterogeneous world - it is hard to say if that term for Bauman refers to the acceptance of all social behaviours. Thus, in the presented work it will be treated mostly as a pluralism of opinions). What is important: "for Bauman, it is democracy that is the ultimate guarantor of individual freedom, not the other way round (...), the individual agent cannot be imagined, let alone talked about alone; social action should not be understood as taking place in a vacuum or 'starting from scratch'; that human lives are lived together is a given, because they are by necessity built on social relations. In other words, for Bauman, "structure and agency leap together" explains Tony Blackshaw [Blackshaw 2005: 10]. For Arendt, actions build the sphere.

Another question which could occur after a given explanation would have the following shape: what does power mean for the Polish sociologist? Is it possible to give only general solutions in an enigmatic clarification? Bauman: "any impoverishment of grass-root ability to articulate interest and self-govern (...), each step towards the weakening of the social foundations of political democracy make a social disaster on a Holocaust scale" [Bauman 2000: 115]. Social foundation and political democracy are two sides of democracy in general. Government, political decisions require legitimization which could be given by members of a society. Power will refer to acts of creation the social regulations. Power is the ability to manage the social relations through a set of laws.

To conclude, democracy for Bauman means pluralism of standpoints which could be articulated and implemented. It contains two elements: opinions formed by critical reasoning and organization of social life - rules, institutions, etc. which allow their realization.

\section{THE COLLAPSE OF DEMOCRACY}

The collapse of democracy in Arendt's terms is deeply connected with her concept of freedom. In her description, the public sphere started to fall with the occurrence of social claims. She explains that the attitude spread only among court members - especially Louis the XIV's Versailles. With the French Revolution it has been extended to all people [Arendt 1961 (I): 199-200]. "Arena" which used to be reserved for disinterested action, becomes a "place" to articulate everybody's needs.

The collapse of democracy refers to the situation when people stopped caring about making glorious things - showing their uniqueness - searching for participation in politics. They do not pay attention to anything but being satiated and having fun. Their interactions with other people are only dependent on "what they will get?".

8 A laconic explanation given in the presented work is a result of a restricted convention of an utterance. Arendt is explaining mentality (general tendencies in people's attitude) of mass society member in the following terms: loneliness, excitability and lack of standards, inability to judge, egocentricity. The frame of that work does not allow to explain them, especially it would require references to many parts 
That critique struck into something which - in Arendt's terms - was social, deprived of freedom. In 1975, a couple of months before her death she had published Home to Roost. From the perspective of almost thirty years after the Second World War, she reproached all symptoms of the crisis of the Republic - the form of government and its institutions of political freedom. McCarthyism, the Vietnam War, Watergate they slowly crumbled exemplars of public life - Arendt wrote [Arendt 1975]. She did not care of economical, diplomatic or inter party system consequences. She was anxious because of disintegration of common life - plurality which acts together.

For Arendt, destroyed democracy means removing requirement of political freedom from the public life. It refers to a selfish action for own goodness, lack of political bounds and the absence of participation in decision-making process. Freedom, in her sense, is the actual action: it is taking place only when it proceeds in between many. Egoistic, egocentric, lonely peoples are not interested in and not able to build political bounds. Plurality which is the condition of political freedom is abandoned. Simply, in a modern society, freedom which is constitutive for democracy stopped to exist.

Bureaucracy, administration and social designing are the biggest opponents of democracy for Bauman. Sin which was committed by the modern society consists in developing administration fields instead of involving themselves in the decision-making process. For the Polish writer, modern people are subordinated to instrumental rationality [Bauman 2000: 115]. They are looking for the most efficient solutions for every case. Experiments and experts have the highest values. Knowledge which could be proven by a given expertise is placing people in social hierarchy [Bauman 2000: 198]. The really significant problem lies in rejection of old authorities as experts. Such a step refers to the doubt of usefulness of communal impact in fully effective social process. As he explains: traditional authorities were uncomfortable for the modern world because "first, they left the primeval, communal controls of order intact (...); second, they weakened (...) the possibility of organized action on a supra-communal level" [Bauman 2000: 112].

For Bauman, functionalism is the principle of a modern state. It arises from instrumental rationality. The utility of a thing is measured by its capability of reaching a particular aim. Calculation is leading to the optimal outcome, is excluding ineffective factors: a social decision and those who were defending it: old authorities. In the described order there is no place for plurality of opinions. Consensus and communication is replaced by the command and administration [Bauman 1992: 23].

Participation democracy was changed into bureaucracy, which means sets of experts responsible for particular tasks. They have their part to do and they are trying to make it perfect. As the author of Liquid Modernity explains: "knowledge of final outcome is redundant, and certainly irrelevant as far as the success of his own [member of administration] part of the operation goes" [Bauman 2000: 100].

of Arendt's philosophy. Thus, they will be left only as indicators of the main thought described above. H. Arendt, Between Past..., pp. 198-199. 
Described "switch" has its own price. Bureaucracy is followed by a huge danger. Using Bauman's words: “ [it] is not merely a tool, which can be used (...) at one time for cruel and morally contemptible, at another for deeply humane purposes (...). Bureaucracy is more like a loaded dice. It has a logic (...). It renders some solutions more, and other solutions less probable" [Bauman 2000: 104]. Logic, which was mentioned above, could be described in the following terms: effect of distance; functional division of labor; cost of effects. Work on some task is divided according to calculation of its effectiveness. According to Bauman, people employed in administration, or ,better said, with an administrative attitude are dealing with the sense and not with the object. They have their own tables and graphs; they are not watching enemies but objects which need to be removed by pressing a button [Taylor 2010: 154].

"Democracy where critique becomes a cliché, being for the other becomes living with the abyssal other in fearful competition, and freedom of expression in public becomes freedom to pursue recognition through fame and conspicuous consumption" [Featherstone 2010: 135] - Mark Featherstone explains Bauman's concerns.

For the Polish thinker, the collapse of democracy means substituting participation democracy by administration, pluralism of standpoint by functional division of labor.

\section{THE JEWISH QUESTION}

In the presented paper, the Jewish question will have two meanings. The first one is connected with K. Marx's On the Jewish Question. This is an issue of the Jews' position in the society; the problem of separateness and the reason for their alliance. Marx explains: "We are trying to break with the theological formulation of the question. For us, the question of the Jew's capacity for emancipation becomes the question: What particular social element has to be overcome in order to abolish Judaism?" [Marx 1844: 21]. He leaves the problem of the Jew's belief and focuses on social relations. As he continues further: "let us consider the actual, worldly Jew - not the Sabbath Jew (...), not look for the secret of the Jew in his religion, but let us look for the secret of his religion in real Jew (...), self-interest (...), huckstering (...), money" [Marx 1844: 21]. The second form of the question is connected with experience of the Holocaust. That problem could be concluded in simple: "Why Jews?". Both forms could be found in Arendt's and Bauman's thoughts.

Arendt distinguishes a social and political problem of the Jewish case. The first one is the matter of acceptance by society, other Jews and themselves. The second refers to minority rights. ${ }^{9}$ Following R. J. Bernstein's thought, the social problem in Arendt's books has two meanings. The first one refers to the figure of parvenu,

9 H. Arendt, The Origins of Totalitarianism, Harcourt, San Diego, London, New York 1976, pp. $55-56$. 
the second refers to the description of the concept of pariah [Bernstein 1996: 22]. Arendt believes these were the two ways which the Jews were choosing when facing the requirement of association. In The Origins of Totalitarianism, she mentions the category of average Jews. They were different from the other two, because they had no consciousness of choice. They treated their successes and failures as an effect of their Jewish roots [Arendt 1962: 67].

For Arendt, the Jewish question is connected with the identity of the Jew. In the background, there is placed social perception of Moses' tribe as a result of the Jews' self-defining. Parvenu as she explains: "[had] brilliant individual careers and been granted considerable privileges by theirs masters, they formed community of exceptions (...), they stood, in a sense, as far outside Jewish society as they did outside Gentile society" [Arendt 1962: 63]. That was a way of assimilation - climbing on a social ladder. The paradox lies in that they were trying to sink into society - avoid their Jewish roots - but they were using the Jewish privileges to reach higher social levels. They were strangers among themselves and other people.

Pariah is an outsider which is caring for his own identity. Bernstein emphasizes that in Arendt's view, assimilation requires members of a society being the same [Bernstein 1996: 44]. Pariah's choice is limited to two options: living in pace with society but avoiding one's own identity or keeping itself but becoming a rebel. The article Jew as a pariah introduces four types of outsiders and also suggests a lack of alternatives in the existence of Jews [Arendt 1978 (I)]. Assimilation requires quieting the fact of being a Jew and for Arendt that is impossible. ${ }^{10}$

Figures of parvenu and pariah describe social side of the Jewish question. The main problem lies in the fact that the question has become a political issue as well. According to Arendt, in the $19^{\text {th }}$ and $20^{\text {th }}$ centuries, Jews had the same status as minorities in the national state. They were protected not by the acceptance of a dominant nation (in other terms they were not equal) but their status was guaranteed by the external treaties and laws [Arendt 1962: 270]. The Nazis used the question as a political tool. The "average Jew" becomes the "Jew everywhere and nowhere" as Arendt explains [Arendt 2007 (III): 93]. The Jewish problem, which originally had a social overtone, happened to be an ideological instrument of manipulation. The real aim of Nazi leaders - total domination - was hidden behind the ideological cliché. Antisemitism raised on the Jewish question received a purpose to give

${ }^{10}$ R. J. Bernstein pays attention to Arendt's concept of Jewishness as a thing which cannot be avoided by Jew. They are able to quit Judaism but never do it. He gave a wide critique of that concept as problematic and having not sufficient explanations. In other place of his book he is describing Arendt's distinction on state liberty and personal freedom - which is understood as a lack of life necessities, utilitarian and other pressure. It looks like a solution for Bernstein's doubts could be found in Arendt's concept of human condition. It could be interpreted as an individual existence under conditions (they were explained up above). In this way, Jewishness will equal to each Jew human condition. In this term, avoiding it will mean quieting yourself - lack of freedom to develop own personality. R. J. Bernstein, Arendt and the Jewish Question..., pp. 29-31. 
masses a goal of realization. To Führer and his closest surrounding, it had a different meaning - it masked their true endeavour: omnipotence (total domination) [Arendt 1962: 385-387, 437-438].

For Arendt, totalitarianism is a system aspired to poses and rule subordination without any borders. The final aim of death camps was not the extermination of people, but the annihilation of their personalities (uniqueness and ability to being spontaneous) [Arendt 1962: 458].

From that perspective the German philosopher is giving two solutions of the problem: why Jews? First, Jews were perceived by the society as having an independent behaviour. The second solution lies in eternal hostility [Arendt 1962: 8].

Independent behaviour, basically for Arendt, means described figures of the average Jew, parvenu and pariah. More interesting is the category of eternal hostility. She blames Jews because of their historiography resulting in miscarrying of political involvement. She describes Jews' understanding of antisemitism in terms of messianic role in history. They believed that all catastrophes which affected them were the effect of their unique predestination. They were treating symptoms of hostility as normal. They found them as helpful in keeping them bound together [Arendt 1962: 7-9]. This mistake made Theodor Herzl and his successors [Arendt 2007 (V): 375-376]. Arendt was convinced that antisemitism in any case cannot be treated as a useful phenomena to Jews. From her point of view, Jewish leaders lacked understanding of political matters. They stayed ignorant to one main fact: equality comes from action, freedom means participation. The greatest Jews' mistake was - in Arendt terms - of political character. Lack of interest in participation in decision-making process - freedom - placed them in a miserable social position. They were deprived of acceptance which, for Arendt, was born in action. Acting together with other nations could bring Jews the equality - the acceptance due to cooperation side by side with others. "For two hundred years we have let ourselves be convinced that the surest way to survive is to play dead" [Arendt 2007 (IV): 165] - she wrote critically. Pretending dead meant the absence of collective effort in politics. Paraphrasing Arendt: Jews abandoned all patterns of democracy but, for them, democracy did not collapse it had simply no meaning.

Bauman in Modernity and the Holocaust is describing social relations between Jews and their surroundings then explaining roots of their alienation. It is possible to find four descriptions of such a relation: 1) theory of an alien inside of mobile class 2) antisemitism as a substitution of anticapitalism 3) internationals in times of nationalism 4) reference to Christianity. Giving the description of features of the diaspora could be partially responsible for such a situation from the Jewish side. He mentions: the sheer length of history time (diachronic continuity and synchronic identity), self-reproducing capacity, universality of homelessness [Bauman 2000: 34-35]. Those characteristics could refer to the cause of Jewish disintegration with society but the problem looks like it is more sophisticated. Let us research given theories for the purpose of receiving a wider perspective on the whole thought. 
Bauman: "They assimilated themselves to their own assimilation, since this was the only place where they could go. Kafka caught it very well, using the metaphor of a four-legged animal: its hind legs have already left the ground but the fore-legs cannot find a place on which to rest" [Bauman, Kilminster, Varcoe 1990: 227]. It was a situation of contingency and choice, they had to choose the assimilation and abandonment of Jewishness, or their own identity instead of relations with society. That was contradiction without solution. "I "I propose that the conceptual Jew has been historically construed as the universal "viscosity' of the Western world" [Bauman 2000: 40] - wrote Bauman. The following citation stands for all categories mentioned above. Universal viscosity includes all four given explanations. Jews could be placed as a cause of every social problem. The very important thing which needs to be underlined is connected with the conceptual character of the Jew as visqueux. Firstly, concepts always belong to somebody; secondly, Bauman emphasizes the conceptual character as different from the experienced relations with Jews. In this way, the Polish sociologist shifts the Jewish question from "how do the Jews and their surroundings coexist?" to "how does the society treat them?". Also, in that question they is treated as a general category - the conceptual Jew. In such a case, people are not dealing with a Jewish neighbour, friend, known person but with an imaginary object.

In summary, Bauman's question is found on social relations but specifically consists in social reception of Moses' tribe.

Confirmation of that hypothesis can be found in descriptions in the above mentioned four categories. Bauman accepts perspective of a Polish researcher, Anna Żuk, who is describing Jews as a mobile class in feudal times. To use his words: "mobile class [means] subject of emotions usually directed by the more highly-placed social groups to the lower classes, and conversely". Further he explains: "what made the Jewish placement in the class war truly special was that they had become objects of (...) mutually opposed (...) class antagonisms" [Bauman 2000: 44, 45]. On the basis of the text, it is hard to say how the author is treating the presence of antagonism in a class society. It looks like he is referring to the past situation without explaining its logic. He is placing Jews in that "world" as strangers who are the victims of all classes' frustrations.

Discussing the second point of Bauman's explanation, the best way to show his idea is to use the same example. The author of Culture as Praxis is making reference to Marx and his concept of the Jew [Bauman 2000: 48]. Even in this writing, when Marx's theory was partially introduced, he is able to recognize the connection

${ }^{11}$ For Bauman, contingency and choice characterize the contemporary society. "Nothing is given; everything must be made" - there are no evident choices, all of them are subject to risk. Z. Bauman, R. Kilminster, I. Varcoe, 1990. Sociology, postmodernity and exile: an interview with Zygmunt Bauman, [in:] Z. Bauman, Intimations of Postmodernity, Routledge London, New York. Z. Bauman, 1992. Intimations of Postmodernity, Routledge London, New York, and Z. Bauman, 2002. The 20th Century: the End or a Beginning?, "Thesis Eleven", no. 70. 
of antisemitism with anticapitalism. He is researching Jews as those whose God is mammon and whose practical view is equal with self-interest. That means that the Jew was recognized as a part of society which was having money. Still, the main point of analyzing the thought lies in perceptions of Jews and not in their characteristics.

For Bauman, the problem of the Holocaust is bound with his theory of democracy collapse. What he describes as politics is opposite to social solutions in public sphere. The term politics describes a functional way of thinking. From the perspective of the final aim, all behaviours are considered as functional or dysfunctional. Only a particular idea is treated as valid - there is no place for diversity of views. Everything that has no purpose to the final outcome does not matter. Politics could be identified with bureaucratic attitude. Logic of it, the same as a dice, could give a certain outcome with different results. One of possibilities leads to mass murder.

According to the given explanation, the Polish thinker answers the main question of that paragraph in the following way: "For the thousand-year Reich - the kingdom of the liberated German Spirit (...), kingdom which had no room for anything but the German Spirit (...), had no room for the Jews" [Bauman 2000: 68]. In the functional logic of the plan, to reach full development of Germans, there was no place for aliens.

\section{CONCLUSIONS}

Similarity between concepts of democracy lies in assigning a big role to heterogeneity by both authors. They have the same view that plurality and participation in the decisive process are building democracy. For both thinkers, plurality of opinions and diversity of human characters are more than important for the public sphere. Arendt is looking for personal peculiarity of man. Every single human being has his/her own human condition, which the highest level of development is the public sphere. The roots of difference lie in human existence, not in the activity of thinking (thinking, judging willing are activities that are displays of human condition). Communal impact for Bauman could be described in terms of participating democracy but only from the point where democracy is seen as an effect of plurality. People are different; they have different opinions and they could and wish to try their implementation. If we investigate the roots of variety in both cases they will have their own explanations. For the Polish thinker, diversity of standpoints is a result of human critical activity.

In understanding freedom, a difference can be found. Arendt's understanding of political freedom does not include taking care of living necessities and utilitarian aims. In her view, a healthy public sphere is free of careerists, nepotism and similar. Freedom, in her terms, does not mean opportunities, it refers to action. It is of actual - not potential - character. Even though Bauman in Modernity and the Holocaust is not giving description of freedom, it is possible to deduct some problems from his thought. If a rational critic of surrounding gives the base for plurality and that situation is desirable, both conceptions will exclude from democracy different things. If 
freedom means: having right to one's own opinion and the opportunity to realize it. The Polish thinker's philosophy cannot avoid public sphere persons who are looking for profits. Their standpoints need to find a place in a social context as one of a variety of opinions. The only barrier is constituted by the prohibition of enforcement.

Importance of participation in public life is the biggest similarity between Bauman's and Arendt's thoughts. Concepts of freedom for both theories have different consequences. Democracy for Arendt means sphere without actions being determined by living necessities or an external pressure. Bauman explains the mentioned term by referring to plurality of opinions and opportunity to its implementation. Both writers do not give complex explanations about organization of the democratic state. They emphasize points which they treat as key issues.

Even in the biggest difference, which refers to their explanations of roots of the Nazi system and the Holocaust event, the main thesis is its legitimization. Bauman is blaming bureaucratic solutions of governing. People are not interested in public life. They leave decisive actions to the experts in that profession. The problem with this solution lies in logic of administration - it does not care about people.

What is important for the main hypothesis in a drawn vision, participation still plays a main role. Substituting one's own presence in public life with the bureaucratic system is the main idea of Bauman's critic. Arendt perceives collapse of democracy in terms of developing social care. Members of society are pushing responsibility of their own lives on others. They stop caring about politics; they only need public support and fun. Individuals are not anxious about politics. They are looking for benefits. That presence in communal life is even worst than Bauman's lack of its attendance. With developing social complaints they envelop public sphere, they become lonely - without political bounds and freedom - crowd.

Even in the standpoint on the Jewish question, there is the importance of public attendance. Arendt investigates identity of Jews and its social reception. She blames Moses' tribe for miscarriage of political engagement. The status of parvenu or pariah - as she explains - only for the Jews had no political meaning. Bauman sees that problem differently. He explains the Jews status as an outcome of social antagonism and their alien appearance. Only in that point there is no connection with public engagement.

To answer the initial aims, experience which comes from that work is attached to the importance of public actions. Critical points of view and unselfish actions make the foundation of the desirable world in both conceptions. Opportunity of participation in a communal decision is not sufficient to build the public sphere. Engagement is strongly required. Maybe with such awareness we will be able to avoid history repentance. 


\section{BIBLIOGRAPHY}

Arendt, H. 1954. Europe and the Atom Bomb, "Commonweal", 60/24.

Arendt, H. 1961 (I). Between Past and Future, The Viking Press, New York.

Arendt, H. 1961 (II). What is Freedom?, [in:] Between Past and Future, J. Kohn (ed.),The Viking Press, New York.

Arendt, H. 1962. The Origins of Totalitarianism, Meridian Books, Cleveland and New York.

Arendt, H. 1971. Lying in Politics: Reflections on The Pentagon Papers, "New York Review of Books", 17/8.

Arendt, H. 1975. Home to Roost, "New York Review of Books", no. 26, July.

Arendt, H. 1978 (I). Jew as a pariah, Grove Press.

Arendt, H. 1978 (II). The Life of The Mind, Harcourt Inc, London, San Diego, New York.

Arendt, H. 1990. On Revolution, Penguin Books.

Arendt, H. 1994 (I). The Seeds of a Fascist International, [in:] Essays in Understanding 1930-1953. Formation, Exile, and Totalitarianism, J. Kohn (ed.), Schocken Books, New York.

Arendt, H. 1994 (II). The Eggs Speak Up, [in:] Essays in Understanding 1930-1953. Formation, Exile, and Totalitarianism, J. Kohn (ed.), Schocken Books, New York.

Arendt, H. 1994 (III). Europe and the Atom Bomb, [in:] Essays in Understanding 1930-1953. Formation, Exile, and Totalitarianism, J. Kohn (ed.), Schocken Books, New York.

Arendt, H. 1998. The Human Condition, University of Chicago Press.

Arendt, H. 2000. Kondycja ludzka, Aletheia, Warszawa.

Arendt, H. 2007 (I). Polityka jako obietnica, Prószyński i S-ka, Warszawa.

Arendt, H. 2007 (II). The promise of politics, Schocken Books, New York

Arendt, H. 2007 (III). Antisemitism, [in:] The Jewish Writings, J. Kohn, R. H. Feldman (eds.), Schocken Books, New York.

Arendt, H. 2007 (IV). With Our Backs to the Wall, [in:] The Jewish Writings, J. Kohn, R. H. Feldman (eds.), Schocken Books, New York.

Arendt, H. 2007 (V). The Jewish Writings, Schocken Books, New York.

Arendt, H., Reif, A. 1972. Thoughts on Politics and Revolution: a Commentary, [in:] Crises of the Republic: Lying in Politics, Civil Disobedience On Violence; Thoughts on Politics and Revolution, Harvest Books, San Diego, New York, London.

Bauman, Z., Kilminster, R., Varcoe, I. 1990. Sociology, postmodernity and exile: an interview with Zygmunt Bauman, [in:] Z. Bauman, Intimations of Postmodernity, Routledge London, New York.

Bauman, Z. 1992. Intimations of Postmodernity, Routledge London, New York.

Bauman, Z. 2000. Modernity and the Holocaust, Cornell University Press, New York.

Bauman, Z. 2002. The 20th Century: the End or a Beginning?, "Thesis Eleven”, no. 70.

Bernstein, R. J. 1996. Arendt and the Jewish Question, MIT Press, Cambridge, Massachusetts.

Blackshaw, T. 2005. Zygmunt Bauman, Routledge, London, New York.

d'Entreves, M. P. 2001. The Political philosophy of Hannah Arendt, Taylor \& Francisr e-Library.

Featherstone, M. 2010. Event Horizon: Utopia-Dystopia in Bauman's Thought, [in:] Bauman's Challenge: Sociological Issues for the 21st Century, M. Davis, K. Tester (eds.), Palgrave Macmillan.

Heller, A. 1987. Hannah Arendt on the 'Vita Contemplativa', "Philosophy and Social Criticism", 12/4.

Hudzik, J. P. 2002. Wyktady z filozofii polityki, UMCS, Lublin.

Kohn, J. 2000. Freedom: the priority of the political, [in:] The Cambridge Companion to Hannah Arendt, D. Villa (ed.), Cambridge University Press, Cambridge.

Marx, K. 1844. On The Jewish Question, http://www.marxists.org/archive/marx/works/1844/jewish-question/ (access 27.08.2014).

Matynia, E. 2009. Performative Democracy, Routledge.

Ricoeur, P. 2006. Power and Violence, [in:] Hannah Arendt. Critical Assessments of Leading Political Philosophers, G. Williams (ed.), vol. 3, Routledge, London, New York.

Szczepański, J. 2009. Polityczna władza sądzenia, WUJ, Kraków. 
Taylor, P. 2010. Totalitarian Bureaucracy and Bauman's Sociological Imagination: In Defence of the Ivory Tower, [in:] Bauman's Challenge: Sociological Issues for the 21st Century, M. Davis, K. Tester (eds.), Palgrave Macmillan.

Villa, D. 1996. Arendt and Heidegger. The fate of the Political, Princeton University Press.

\section{ABOUT THE AUTHOR}

Radoslaw Harabin, a doctoral student in the Department of Political Philosophy and Sociology at the Faculty of Political Science of the Maria Curie-Skłodowska University. He graduated (with commendation) from the Jagiellonian University in Kraków with a Master's degree in philosophy. He also completed his studies in the field of political science at the Jan Kochanowski University in Kielce. In 2013, he received a scholarship founded by Transregional Center for Democratic Studies in New York. E-mail address: harabinradek@o2.pl 